\title{
Is There a Relationship between Clinical Symptoms of Asthmatic Children and Serum Levels of Vitamin D and Zinc?
}

\section{Astımlı Çocukların Serum D Vitamini ve Çinko Düzeyleri ile Klinik Bulguları Arasında Bir İlișki Var mı?}

\author{
Zehra Șule Haskoloğlu' ${ }^{1}$ Demet Altun² \\ ${ }^{1}$ Ankara University, Faculty of Medicine, Department of Pediatric Allergy and Immunology \\ ${ }^{2}$ Ufuk University, Faculty of Medicine, Department of Pediatrics, Ankara
}

\begin{abstract}
Objectives: It is reported that deficiencies in vitamin D and zinc are associated with asthma. In this study we aimed to investigate the relationship between clinic findings of asthmatic children and vitamin $\mathrm{D}$ and zinc levels.

Materials and Methods: This prospective study included a total of 149 asthmatics and 97 healthy children with an age range of 5 to 17 years. All of the participants were evaluated for serum levels of 25 hydroxyvitamin $\mathrm{D}(25 \mathrm{OH}) \mathrm{D})$ and zinc, dietary habits, the rate of respiratory tract infections, hospital visits and levels of sunlight exposure.

Results: Serum vitamin D and zinc levels in asthmatic children $(7.7 \pm 5.29 \mathrm{ng} / \mathrm{ml}),(64 \pm 16.3 \mathrm{mcg} / \mathrm{dl})$ were significantly lower than that in healthy children $(12.3 \pm 12.87 \mathrm{ng} / \mathrm{ml}),(69 \pm 26.2 \mathrm{mcg} / \mathrm{dl})(\mathrm{p}<0.015)$, respectively. A relationship was detected between the frequency of infection and vitamin $D$ level's being $<10 n g / \mathrm{ml}(\mathrm{p}<0.001)$, while no relationship was detected between the frequency of infection and zinc level. No relationship was detected between pulmonary function, nutrition and the levels of vitamin $\mathrm{D}$ and zinc. However, a relationship was detected between vitamin D levels and exposure to sunlight. Conclusion: Our results showed that asthmatic children had lower vitamin D and zinc levels than healthy children. Very low levels of vitamin D were found to be associated with an increased rate of infection and required more medication and hospitalization.

Key words: Asthmatic children, level of vitamin D, level of zinc, clinical symptoms
\end{abstract}

$\ddot{O} \mathbf{z}$

Amaç: Vitamin D ve çinko eksikliğinin astım ile ilişkili olduğu bildirilmektedir. Bu çalışmada astımlı çocukların klinik bulguları ile vitamin D ve çinko düzeyleri arasındaki ilişkiyi araştırmayı istedik. Materyal ve Metot: Bu prospektif çalıșmaya yaşları 5-17 arasında değișen 149 astımlı ve 97 sağlıklı çocuk dahil edildi. Tüm katılımcıların serum 25 hidroksivitamin D $(25(\mathrm{OH}) \mathrm{D})$ ve çinko düzeyleri ölçüldü, diyet alışkanlıkları, bir yıldaki solunum yolu enfeksiyonu sıklıkları, hastane başvuruları ve güneș ışı̆̆ına maruziyet süreleri sorguland.

Bulgular: Astımlı çocukların serum D vitamini ve çinko düzeyleri sırasıyla $(7,7 \pm 5,29 \mathrm{ng} / \mathrm{ml}),(64 \pm 16,3$ $\mathrm{mcg} / \mathrm{dl})$ sağlıklı çocuklardan $(12,3 \pm 12,87 \mathrm{ng} / \mathrm{ml}),(69 \pm 26,2 \mathrm{mcg} / \mathrm{dl})$ belirgin şekilde düșük bulundu (p $<0,001)(\mathrm{p}<0,015)$. Serum D vitamini düzeyinin ıng/ml'nin altında olması ile enfeksiyon sıklığı arasında ilişki bulunurken çinko düzeyi ile ilişki saptanmadı. Pulmoner fonksiyonlar, beslenme ile D vitamini düzeyi arasında ilișki saptanmadı. Ancak güneșe maruziyet ile $\mathrm{D}$ vitamini düzeyi arasında bir ilișki saptandi.

Sonuç: Bizim sonuçlarımız astımlı çocukların sağlıklı çocuklardan daha düşük D vitamini ve çinko düzeyine sahip olduğunu göstermektedir. D vitamininin çok düşük düzeylerde olması artmıș enfeksiyon riski, daha çok tedavi ihtiyacı ve hastane yatışı ile ilişkili ulundu.

Anahtar kelimeler: Astımlı çocuk, vitamin D düzeyi, çinko düzeyi, klinik bulgular

\section{Correspondence / Yazıșma Adresi:}

Dr. Zehra Şule Haskoloğlu

Ankara University, School of Medicine, Department of Pediatric Allergy and Immunology,

Ankara / Turkey

e-mail: zsireci@yahoo.com

Date of submission: 11.09.2018

Date of admission: 14.12 .2018 
Is There a Relationship between Clinical Symptoms of Asthmatic Children and Serum Levels of Vitamin D and Zinc?

\section{Introduction}

Asthma is the most common chronic childhood disorder worldwide. ${ }^{1}$ The prevalence of asthma and allergic diseases in children has increased in recent years. ${ }^{1-2}$ Environmental factors, including infections, diet, passive smoking, closed environments, lack of exercise, and socio-economic conditions, are implicated in the development of allergic diseases. ${ }^{1-2}$ Individual factors associated with genetic characteristics are also implicated, including genetic tendency, atopy, bronchial hyperreactivity, sex, and race. ${ }^{1}$

Environmental changes include modifications in the dietary habits and reduced exposure to sun, leading to reduced circulating levels of vitamin D, which may account for the rise in asthma prevalence. ${ }^{4}$ However, vitamin D supplementation for rickets prophylaxis appears to be responsible for the increased rate of asthma and atopic disease. ${ }^{5,6}$ Deficiencies of micronutrients and vitamins involved in the immune system maturation, may increase the asthma risk.,5 Although the current epidemiological evidence is poor, it is supported that vitamins $\mathrm{A}, \mathrm{D}$, and $\mathrm{E}$, zinc, fruits and vegetables, and a Mediterranean diet could be protective against asthma. 5,6 There are reports on the effects of vitamin D both on the development and prevention of asthma. ${ }^{8-11}$. While vitamin $\mathrm{D}$ contributes to allergy development through the regulatory $\mathrm{T}$ cells, it also generates preventive effects through factors involved in bronchial smooth muscle hypertrophy and hyperplasia. ${ }^{8}$ Vitamin D reduces the prevalence and severity of bacterial and viral infections of the respiratory tract by releasing proinflammatory cytokines by stimulating the expression of antimicrobial peptides during such infections. ${ }^{8,10}$ Several studies report a link between asthma and low levels of vitamin $\mathrm{D}_{-}{ }^{11-13}$ It is usually considered that vitamin D deficiency is correlated with severe asthma attacks, poor asthma control, higher steroid doses, more doctor visits, and hospital admissions. ${ }^{14-18}$

The presence of zinc, an antioxidant element in the respiratory tract epithelium, and its role in regulating cellular and humoral response in the immune system suggest its probable effect in asthma pathogenesis and treatment. Vitamin D increases both the absorption of zinc and its delivery to the bones. Reduced zinc intake may increase atopy, and bronchial reactivity and thus allergic symptoms become evident. There is a reverse link between the serum zinc levels and wheezing. ${ }^{19}$ To contribute to the literature, in this study, we aimed to investigate the relationship between vitamin D with zinc levels in asthma patients considering dietary habits and other factors associated with living conditions.

\section{Materials and Methods}

In this prospective study, the study group consisted of a total of 149 children with asthma, aged 5 to 17 years, who were diagnosed by a pediatric allergy specialist in accordance with the Global Initiative for Asthma (GINA) criteria. These children were also followed up for at least one year at the Pediatric Allergy Department of Cumhuriyet University, School of Medicine, Sivas, Turkey. The patients were excluded from this study if they were receiving daily or slow-release vitamin D or zinc supplementation, or if they had antibody deficiency, chronic liver or kidney diseases or malnutrition. The control group was comprised of 97 healthy children, aged 5 to 17 years, who were admitted to the general pediatric polyclinic. This study was approved by the Ethics Board of the Faculty of Medicine of Cumhuriyet University according to 
Is There a Relationship between Clinical Symptoms of Asthmatic Children and Serum Levels of Vitamin D and Zinc?

Helsinki Declaration. The study procedure and aim of the present research were explained to the participants' parents, and a written informed consent was obtained from each parent.

\section{Assessment of children}

Questions were asked to obtain participant information about the following: inhaled steroid use and dose, number of respiratory tract diseases within the previous year, the number of emergency admissions and hospitalizations, and the number of asthma attacks and systemic steroid intake. We also obtained data relating to dietary habits, family income levels and residency. Patients were subjected to the following tests: whole blood count, total Ig E level, skin prick test, respiratory function test, and stool parasite scans.

\section{Measurements of serum 25-hydroxyvitamin D (25(OH)D) and zinc levels}

For the serum $25(\mathrm{OH}) \mathrm{D}$ level assay, an enzyme-linked immunosorbent assay (ELISA) kit (Cat. No.: K 2110, Immun diagnostik, Bensheim, Germany) was used. The results were read by an Elisa plate reader at $450 \mathrm{~nm}$ and calculated as $\mathrm{nmol} / \mathrm{L}^{16}$. Serum zinc levels were measured by the direct colorimetric method using a serum zinc level assay kit (Cat. No. 17640, Sentinel Diagnostic, Milan, Italy) in a Beckman Coulter L×20.

\section{Statistical analysis}

Statistical analysis was performed using SPSS 15.0 statistical software (SPSS Inc., Chicago, IL, USA. The Pearson chi-square test $\left(\mathrm{x}^{2}\right)$ was used to compare the differences between the groups. The appropriate Kolmogorov-Smirnov test was used to analyze the normal distribution of variables. The Mann-Whitney U test was used to analyze abnormally distributed variables. Abnormally distributed continuous variables were expressed in median (min-max), while categorical variables were presented in frequency and percentage. The Spearman's correlation analysis was used to analyze ordinal and scale variables. A $p$-value of $<0.001$ was considered statistically significant.

\section{Results}

Total of 149 patients, 83 were males and 66 were females with a mean age of $10.23 \pm$ 2.37 (range: 5 to 17 ) years. The healthy control group was comprised of a total of 51 ageand sex-matched males and 46 females with a mean age of $9.32 \pm 2.41$ (range: 5 to 17 ) years. Demographic characteristics of the study population are presented in Table 1.

Table 1. Demographic characteristics of the study population

\begin{tabular}{|l|c|c|c|}
\hline & $\begin{array}{c}\text { Children with asthma } \\
(\mathrm{n}: 149)\end{array}$ & $\begin{array}{c}\text { Healthy controls } \\
(\mathrm{n}: 97)\end{array}$ & p-value \\
\hline Gender & $66(44 \%)$ & $46(48 \%)$ & \\
Female & $83(56 \%)$ & $51(52 \%)$ & $>0.05$ \\
Male & $10.23 \pm 2.37$ & $9.32 \pm 2.41$ & $>0.05$ \\
\hline Age & $7.7 \pm 5.29$ & $12.3 \pm 12.87$ & 0.001 \\
\hline Vitamin D (ng/ml) & $64 \pm 16.3$ & $69 \pm 26.2$ & 0.015 \\
\hline Zinc $(\mathbf{m c g} / \mathbf{d l})$ & & & \\
\hline
\end{tabular}


Is There a Relationship between Clinical Symptoms of Asthmatic Children and Serum Levels of Vitamin D and Zinc?

The $25(\mathrm{OH}) \mathrm{D}$ levels in the asthmatic children were significantly lower than the healthy children. The mean serum $25(\mathrm{OH}) \mathrm{D}$ levels of the asthmatic children were $7.7 \pm 5.29$ $\mathrm{ng} / \mathrm{ml}$ and $12.3 \pm 12.87 \mathrm{ng} / \mathrm{ml}$ for the control group. The $25(\mathrm{OH}) \mathrm{D}$ levels in 147 children with asthma $(98.65 \%)$ and 85 healthy children $(87,62 \%)$ in the control group $(\mathrm{n}=97)$ were under $20 \mathrm{ng} / \mathrm{ml}$, which indicates a statistically significant difference between the two groups ( $\mathrm{p}=\mathrm{0.001}$, Table 1 ). The mean serum zinc levels of the asthmatic children were $64 \pm 16.30 \mu \mathrm{g} / \mathrm{dL}$ and $69 \pm 26.20 \mu \mathrm{g} / \mathrm{dL}$ for the control group ( $\mathrm{p}=0.015$, Table 1 ).

Annual hospital visit rate with RTI in asthmatic children was found out to be 3.6 times higher than that of the control group. While there was no difference between vitamin D levels lower than 1ong $/ \mathrm{ml}$ and the prevalence of the RTI in children with asthma, vitamin D levels $<10 \mathrm{ng} / \mathrm{ml}$ in healthy children correlated with increasing prevalence of infection compared to the children with a level of $>10 \mathrm{ng} / \mathrm{ml}(\mathrm{p}=0.001)$, (Table 2 ). No correlation was found between the annual number of RTIs and serum zinc levels in the asthmatic children and the control group (Table 2).

Hospital admittance of children with asthma due to acute asthma attack was $33.60 \%$. There was no relationship between the need for hospitalization and the levels of vitamin $\mathrm{D}$ and zinc $[(\mathrm{p}=\mathrm{o}, \mathrm{0}),(\mathrm{p}=\mathrm{o}, 25)$, respectively]. However, the vitamin $\mathrm{D}$ levels of all hospitalized patients were less than $20 \mathrm{ng} / \mathrm{ml}$, and the zinc levels of all patients who needed more than one hospitalization were also lower.

Table 2. The relation between vitamin D and zinc levels with number of RTI of the study population

\begin{tabular}{|c|c|c|c|c|c|c|}
\hline (2) & $\begin{array}{l}\text { Vitamin D } \\
<\text { long/ml }\end{array}$ & $\begin{array}{l}\text { Vitamin D } \\
\geq 1 \text { long/ml }\end{array}$ & p-value & $\begin{array}{c}\text { Zinc } \\
<75 \mathrm{mcg} / \mathrm{dl}\end{array}$ & $\begin{array}{c}\text { Zinc } \\
\geq 75 \mathrm{mcg} / \mathrm{dl} \\
\end{array}$ & p-value \\
\hline $\begin{array}{l}\text { Children with } \\
\text { asthma n (\%) }\end{array}$ & $\begin{array}{c}121 \\
(81.2 \%)\end{array}$ & $\begin{array}{c}28 \\
(18.8 \%)\end{array}$ & \multirow{2}{*}{0.577} & $112(75.1 \%)$ & $\begin{array}{c}37 \\
(24.8 \%) \\
\end{array}$ & \multirow{2}{*}{0.737} \\
\hline Number of RTI & $5.76 \pm 1.84$ & $5.6 \pm 1.96$ & & $5.76 \pm 1.95$ & $5.64 \pm 1.56$ & \\
\hline $\begin{array}{l}\text { Control group n } \\
(\%)\end{array}$ & $\begin{array}{c}30 \\
(30.9 \%)\end{array}$ & $\begin{array}{c}67 \\
(69.1 \%)\end{array}$ & \multirow[t]{2}{*}{0.001} & $\begin{array}{c}56 \\
(57 \%)\end{array}$ & $\begin{array}{c}41 \\
(43 \%)\end{array}$ & \multirow[t]{2}{*}{0.211} \\
\hline Number of RTI & $1.93 \pm 0.25$ & $1.38 \pm 0.52$ & & $1.5 \pm 0.53$ & $1.63 \pm 0.48$ & \\
\hline
\end{tabular}

Of the 50 patients who used systemic steroids for acute asthma attacks, the $25(\mathrm{OH}) \mathrm{D}$ levels were $<10 \mathrm{ng} / \mathrm{ml}$ in 43 patients $(86 \%)$ and $\geq 10 \mathrm{ng} / \mathrm{ml}$ in seven patients $(14 \%)$ indicated no statistically significant difference $(\mathrm{p}=0,287)$.

The mean inhaled steroid dose of the asthmatic children was $177 \pm 94.11 \mu \mathrm{g}$, and the mean steroid use duration of the patients was $2.36 \pm 2.12$ years. No relation was found between the $25(\mathrm{OH}) \mathrm{D}$ levels of these children and the steroid dose used $(\mathrm{r}=-0.009)$.

We also found no correlation between the $25(\mathrm{OH}) \mathrm{D}$ and zinc levels of the children with asthma and their eosinophil counts, total IgE levels presence of atopy (Table 3), the severity of asthma and respiratory function variables, including FEV1, FEV1/FVC, PEF, MEF50, MEF25-75 (Table 4).

No relation was found between the levels of $25(\mathrm{OH}) \mathrm{D}$ and zinc and the amount of food consumed: milk ( $>1$ glass daily, 2 to 3 glasses weekly, $<2$ glasses weekly); yogurt ( $\geq 1$ portion daily, 2 to 3 portions weekly, $<1$ portion monthly); red meat (once daily, 3 to 4 times weekly, <3 times monthly); legumes (once a week, once a fortnight, once a 
Is There a Relationship between Clinical Symptoms of Asthmatic Children and Serum Levels of Vitamin D and Zinc?

month or less); fresh fruit and vegetables ( $\geq 1$ daily, 2 to 3 weekly, $<1$ monthly); fish (once a week, once a fortnight, once a month); nuts (once a week, once a fortnight, once a month or less).

Table 3. Association between vitamin D and zinc levels with eosinophil count, total Ig $\mathrm{E}$ and presence of atopy of asthmatic children

\begin{tabular}{|l|c|c|c|c|}
\hline & \multicolumn{2}{|c|}{ Vitamin D (ng/ml) } & \multicolumn{2}{c|}{ Zinc(mcg/dl) } \\
\hline & $<20(\mathbf{n : 1 4 7})$ & $\geq 20(\mathbf{n : 2})$ & $<75(\mathbf{n : 1 1 1})$ & $\geq 75(\mathbf{n}: 38)$ \\
\hline Eosinophil count $\left(\mathbf{m m}^{3}\right)$ & $340 \pm 293$ & $220 \pm 14.1$ & $340 \pm 2681$ & $350 \pm 352$ \\
\hline p & \multicolumn{2}{|c|}{0.119} & \multicolumn{2}{c|}{0.442} \\
\hline Total IgE (IU/ml) & $217.1 \pm 262.2$ & $15.5 \pm 9.19$ & $110 \pm 245.3$ & $143 \pm 302.6$ \\
\hline p & \multicolumn{2}{|c|}{0.127} & \multicolumn{2}{c|}{0.574} \\
\hline Atopy (+) n:73 (48\%) & $7.9 \pm 7.04$ & - & $62 \pm 16.87$ & - \\
\hline Atopy (-) n:76 (52\%) & $7.5 \pm 2.37$ & - & $66.5 \pm 15.83$ & - \\
\hline p & \multicolumn{2}{|c|}{0.725} & \multicolumn{2}{c|}{0.434} \\
\hline
\end{tabular}

Of the children with asthma, 50 (33.55\%) were from low-income families, 81 (54.36\%) were from middle-income families, while 18 (12.08\%) were from high-income families. No significant correlation was detected between the income levels and vitamin $\mathrm{D}$ and zinc levels $(\mathrm{p}=0.346)$. Of the children with asthma, $109(73.15 \%)$ of the children were living in urban areas, and $40(26.85 \%)$ were living in rural areas. There was no significant correlation between the residency and vitamin $\mathrm{D}$ and zinc levels $(\mathrm{p}=0.388)$.

A significant relationship was observed between the vitamin levels of children and the amount of sunlight in their homes: when the amount of time asthmatic children spend outdoors on sunny days and the levels of vitamin $25(\mathrm{OH}) \mathrm{D}$ are examined, the level was significantly lower for those who spent less than 30 minutes daily $(\mathrm{p}=0.001)$.

Table 4. Correlation analysis between vitamin $\mathrm{D}$ and zinc levels with respiratory function parameters of asthmatic children

\begin{tabular}{|l|c|c|c|c|c|}
\hline $\begin{array}{l}\text { Vitamin D } \\
(\mathbf{n g} / \mathbf{m l})\end{array}$ & FEV1 & FEV1/FVC & PEF & MEF50 & MEF25-75 \\
\hline$<20$ & $85.17 \pm 10.9$ & $100.17 \pm 12.5$ & $86.38 \pm 14.12$ & $86.99 \pm 15.92$ & $90.25 \pm 19.7$ \\
\hline$\geq 20$ & $80.5 \pm 6.36$ & $103.00 \pm 21.21$ & $85.00 \pm 4.24$ & $85.5 \pm 2.12$ & $88.00 \pm 5.65$ \\
\hline $\mathbf{r}$ & 0.481 & 0.621 & 0.864 & 0.889 & 0.851 \\
\hline Zinc (mcg/dl) & FEV1 & FEV1/FVC & PEF & MEF50 & MEF25-75 \\
\hline$<75$ & $87 \pm 11.1$ & $99 \pm 12.3$ & $85 \pm 14.8$ & $87 \pm 16.1$ & $89 \pm 18.8$ \\
\hline$\geq 75$ & $84 \pm 9.9$ & $100 \pm 13.3$ & $87.5 \pm 11.3$ & $84.5 \pm 15.1$ & $86.5 \pm 22.1$ \\
\hline $\mathbf{r}$ & 0.259 & 0.679 & 0.689 & 0.475 & 0.739 \\
\hline
\end{tabular}

\section{Discussion}

While there are various studies that reported positive effects of vitamin D in asthma pathogenesis. ${ }^{13-18}$ There are very few studies that assessed the relationship between the 
Is There a Relationship between Clinical Symptoms of Asthmatic Children and Serum Levels of Vitamin $\mathrm{D}$ and Zinc?

zinc levels and asthma. ${ }^{19-25}$ As vitamin D deficiency increases globally due to changing dietary habits, zinc deficiency also increases.

The present study was conducted in Sivas has shown that vitamin D and zinc levels in children with asthma were lower than the control group. Previous studies of other regions of Turkey reported that zinc and vitamin D deficiency was common in asthmatic children. However, it is notable that, the existing studies in the literature did not find out deficiency levels as low as those found in the present study. . $9,21-24^{2}$

In a four-year cohort study, the Childhood Asthma Management Program, which assessed a total of 1024 North American child with moderate to severe asthma, $35 \%$ of the patients were observed to have insufficient vitamin D levels. In this patient population, the risk of severe asthma attacks and the frequency of emergency visits increased. The Third National Health and Nutrition Examination Survey demonstrated that vitamin $\mathrm{D}$ increased the production of antimicrobial peptides, including cathelicidin, and that a $25(\mathrm{OH}) \mathrm{D}$ level of $<10 \mathrm{ng} / \mathrm{ml}$ constituted a high risk for upper RTIs compared to those with $\geq 30 \mathrm{ng} / \mathrm{ml} .{ }^{15}$ These findings are also consistent with our study results where hospital visit rate with RTI in asthmatic children was found out to be 3.6 times higher than that of the control group. Vitamin D levels less than $10 \mathrm{ng} / \mathrm{ml}$ were also associated with an increased infection rate in healthy children, which suggests that vitamin D deficiency is a contributing factor to the increased RTI rates among children with asthma.

In the present study, Vitamin D levels of all patients who required systemic steroid treatment were $<10 \mathrm{ng} / \mathrm{ml}$. A higher rate of RTIs in children with lower vitamin D levels suggests that vitamin D deficiency may increase the attack frequency and need for systemic steroids.

Studies demonstrated that asthmatic children with low vitamin D levels were more susceptible to allergy, their lung function was poor, and that they received higher doses of inhaled steroid, oral steroid, and long-acting $\beta$ agonists. ${ }^{10,11,14,15,18,26,27}$ The addition of dexamethasone and vitamin $\mathrm{D}$ to $\mathrm{CD}_{4}+\mathrm{T}$ lymphocytes of steroid-resistant asthmatic patients in culture media increased the interleukin (IL) -10 release from these cells, thereby reducing the inflammatory response and contributing to the success of the treatment. ${ }^{28-30}$-In addition, several studies showed that asthma attacks due to upper RTIs reduced in children in whom daily vitamin D supplementation was given ${ }^{17}$. In a recently published meta-analysis identified 483 unique studies, eight of which were eligible randomised controlled trials (total 1078 participants). They sought individual participant data for each and obtained it for seven studies (955 participants). Vitamin D supplementation reduced the rate of asthma exacerbation requiring treatment with systemic corticosteroids among all participants (adjusted incidence rate ratio [aIRR] o.74, 95\% CI o.56-0.97; $\mathrm{p}=0 \cdot 03 ; 955$ participants in seven studies; high-quality evidence). ${ }^{31}$

In the present study, we found no statistically significant relationship between the asthma severity and vitamin D levels and the respiratory functions. However, we had no patients with severe asthma who needed high-dose steroids. As a result, we were unable to form a different group composed of severe asthmatic patients. Additionally, in $98.00 \%$ of the cases in our patient group, the levels of vitamin D were rather low: only two patients had normal vitamin D levels. The prevalence of RTIs was 3.6 times 
Is There a Relationship between Clinical Symptoms of Asthmatic Children and Serum Levels of Vitamin D and Zinc?

higher in children with asthma than in healthy children, which suggests that vitamin D deficiency is a contributing factor to the increased rate of RTIs.

While $10 \%$ of the vitamin D of the body comes from the food, 90 to $95 \%$ is synthesized in the body following the exposure to solar radiation. ${ }^{3,4}$ Geographical latitude, length of exposure to the sun, skin color, protective cosmetics, and clothing all influence vitamin D synthesis. ${ }^{3,4}$ When the amount of time asthmatic children spent outdoors on sunny days and the levels of vitamin $25(\mathrm{OH}) \mathrm{D}$ were examined, we also observed that the $25(\mathrm{OH}) \mathrm{D}$ levels were significantly lower for those who spent less than 30 minutes outdoors daily. The lack of many sunny days in Sivas, with a $39^{\circ} 45^{\prime}$ latitude, $37^{\circ}$ o1 $^{\prime}$ longitude and altitude of $1,270 \mathrm{~m}$, is considered the most important factor leading to vitamin D insufficiency among children living in Sivas.

A study that involves pediatric cases showed that a diet rich in the fish and omega- 3 fatty acid reduced the severity of existing asthma. ${ }^{12,25}$. We also assessed the eating habits of our study population and found out no relationship between the levels of vitamin D and zinc with consumption of milk, yoghurt, red meat, legumes, nuts, vegetables, fruits, and fish. However, in the Sivas province, diet was predominantly cereals, and fish consumption was much lower than recommended: only $10.00 \%$ of the patients consumed fish once a week. These dietary habits may contribute to the vitamin $\mathrm{D}$ deficiencies in the asthmatic patients and control group included in our study.

In developing countries, zinc deficiency is common and manifests itself as a reduction in the immune response and an increase in the rate of infections. Yılmaz et al. found no relationship between the level of zinc and the duration, severity and control level of asthma. ${ }^{19}$. However, the authors revealed that the erythrocyte zinc levels of children hospitalized due to severe asthma attacks were significantly lower than those of asthmatic patients who did not require hospitalization and lower than those of the control group. In another placebo-controlled clinical study of eight weeks that investigated the effects of zinc supplementation in children with asthma, 284 children on inhaled steroids were allocated to receive zinc supplements (50 mg/day) $(\mathrm{n}=144)$ or placebo $(n=140)^{32}$. The patients and controls had low initial serum zinc concentrations. Following treatment, the mean serum zinc level in the patient group was significantly higher than in the controls. The patient group showed significant improvements in clinical symptoms, such as a cough, wheezing and dyspnea, and in all spirometry parameters, including FVC, FEV1, and FEV1/FVC. In the present study, $76.00 \%$ of the children who needed to be hospitalized once had insufficient zinc levels, and all children who needed to be hospitalized twice also had insufficient zinc levels.

Furthermore, the number of RTIs was higher in asthmatic children with lower levels of zinc than in children with normal zinc levels.

In conclusion, our study results showed that asthmatic children had lower vitamin D and zinc levels, compared to the healthy children, and these patients visited hospital more often and required more medication. In the light of these data, we believe that an increased exposure to sunshine, vitamin D enrichment of commonly consumed foods and increased consumption of food with vitamin $\mathrm{D}$ and high-zinc content could reduce asthma attacks and frequency of infection in asthmatic children, ensuring the control of the disease and reducing the number of emergency hospital visits and steroid use. 
Is There a Relationship between Clinical Symptoms of Asthmatic Children and Serum Levels of Vitamin D and Zinc?

Thus, we can conclude that asthmatic children should be evaluated regarding vitamin $\mathrm{D}$ and zinc deficiency and supplementation.

\section{References}

1. $\quad$ Asher I, Pearce. Global burden of asthma among children. Int J Tuberc Lung Dis 2014;18:1269-78.

2. Asher MI, Montefort S, Björkstén B et al. ISAAC Phase Three Study Group. Worldwide time trends in the prevalence of symptoms of asthma, allergic rhinoconjunctivitis, and eczema in childhood: ISAAC Phases One and Three repeat multicountry cross-sectional surveys. Lancet 2006;368:733-43.

3. Litonjua AA, Weiss ST. Is vitamin D deficiency to blame for the asthma epidemic? J Allergy Clin Immunol 2007;120:1031-5.

4. Wjst M, Dold S. Genes, factor X, and allergens: What causes allergic diseases? Allergy 1999;54:757-9.

5. Litonjua AA, Rifas-Shiman SL, Ly NP, et al. Maternal antioxidant intake in pregnancy and wheezing illnesses at 2 y of age. Am J Clin Nutr 2006;84:903-11.

6. Nurmatov U, Devereux G, Sheikh A. Nutrients and foods for the primary prevention of asthma and allergy: Systematic review and meta-analysis. J Allergy Clin Immunol 2011;127:724-33.

7. Devereux G, Turner SW, Craig LC et al. Low maternal vitamin E intake during pregnancy is associated with asthma in 5-year-old children. Am J Respir Crit Care Med 2006;174:499 -507.

8. Damera G, Fogle HW, Lim P, et al. Vitamin D inhibits growth of human airway smooth muscle cells through growth factor-induced phosphorylation of retinoblastoma protein and checkpoint kinase 1. Br J Pharmacol 2009;158:1429-41.

9. Bozzetto S, Carraro S, Giordano G, Boner A, Baraldi E. Asthma, allergy and respiratory infections: the vitamin D hypothesis. Allergy 2012;67:10-17.

10. Ginde AA, Mansbach JM, Camargo CA Jr. Association between serum 25-hydroxyvitamin D level and upper respiratory tract infection in the Third National Health and Nutrition Examination Survey. Arch Intern Med. 2009;169:384-90.

11. Black PN, Scragg R. Relationship between serum 25-hydroxyvitamin D and pulmonary function in the third national health and nutrition examination survey. Chest 2005;128:3792-98.

12. Camargo CA Jr, Rifas-Shiman SL, Litonjua AA, et al. Maternal intake of vitamin D during pregnancy and risk of recurrent wheeze in children at 3 y of age. Am J Clin Nutr 2007;85:788-95.

13. Ginde AA, Sutherland RE. Vitamin D in asthma: Panacea or true promise? J Allergy Clin Immunol 2010;126:59-60.

14. Brehm JM, Celedo'n JC, Soto-Quiros ME, et al. Serum Vitamin D Levels and Markers of Severity of Childhood Asthma in Costa Rica. Am J Respir Crit Care Med 2009;179:765-71.

15. Brehm JM, Schuemann B, Fuhlbrigge AL, et al. Childhood Asthma Management Program Research Group. Serum vitamin D levels and severe asthma exacerbations in the childhood asthma management program study. J Allergy Clin Immunol 2010;126:52-8.

16. Hughes DA, Norton R. Vitamin D and respiratory health. Clin Exp Immunol 2009;158:20-5.

17. Walker VP, Modlin RL. The vitamin D connection to pediatric infections and immune function. Pediatr Res 2009;65:106-13.

18. Bener A, Ehlayel MS, Tulic MK, Hamid Q. Vitamin D deficiency as a strong predictor of asthma in children. Int Arch Allergy Immunol 2012;157:168-75.

19. Arik Yılmaz E, Ozmen S, Bostancı I, Misirlioglu ED, Ertan U. Erythrocyte zinc levels in children with bronchial asthma. Pediatric Pulmonology 2011;4612:1189-93.

20. Park SY, Birkhold SG, Kubena LF, Nisbet DJ, Ricke SC. Review on the role of dietary zinc in poultry nutrition, immunity, and reproduction. Biol Trace Elem Res 2004;101:147-63.

21. Kumar J, Muntner P, Kaskel FJ, Hailpern SM, Melamed ML. Prevalence and association of 25hydroxyvitamin D deficiency in US children: NHANES III. 2001-2004. Pediatrics 2009;124:362-70.

22. Uysalol M, Uysalol EP, Yilmaz Y, et al. Serum level of vitamin D and trace elements in children with recurrent wheezing a cross-sectional study. BMC Pediatrics 2014;14:270.

23. Türe M, Zeyrek DC, Koçyiğit A. Hıșıltılı çocuklarda serum D vitamini, folik asit ve Bı̀ düzeyi. Asthma Allergy Immunol 2013;11:169-77.

24. Gultekin A, Ozalp I, Hasanoglu A, Unal A. Serum 25-hydroxycholecalciferol levels in children and adolescents. Turk J Pediatr 1987;29:155-62.

25. Taneli B. Zinc in Anatolian Population. Ege J Med 2005;44:1-10. 
Is There a Relationship between Clinical Symptoms of Asthmatic Children and Serum Levels of Vitamin D and Zinc?

26. Hodge L, Salome CM, Hughes JM, et al. Effects of dietary intake of omega-3 and omega- 6 fatty acids on severity of asthma in children. Eur Respir J 1998;11:361-65.

27. Turkeli A, Ayaz O, Uncu A, et al. Effects of vitamin D levels on asthma control and severity in preschool children. Eur Rev Med Pharmacol Sci 2016;20(1):26-36.

28. Xystrakis E, Kusumakar S, Boswell S, et al. Reversing the defective induction of IL-10-secreting regulatory $\mathrm{T}$ cells in glucocorticoid-resistant asthma patients. J Clin Invest 2006;116:146-55.

29. Urashima M, Segawa T, Okazaki M, Kurihara M, Wada Y, Ida H. Randomized trial of vitamin D supplementation to prevent seasonal influenza A in school children. Am J Clin Nutr 2010;91:125560.

30. Majak P, Olszowiec-Chlebna M, Smejda K, Stelmach I. Vitamin D supplementation in children may prevent asthma exacerbation triggered by acute respiratory infection. J Allergy Clin Immunol 2011;127:1294-96.

31. Jolliffe DA, Greenberg L, Hooper RL et al. Vitamin D supplementation to prevent asthma exacerbations: a systematic review and meta-analysis of individual participant data. Lancet Respir Med. 2017;11:881-90.

32. Ghaffari J, Khalilian A, Salehifar E, Khorasani E, Rezaii MS. Effect of zinc supplementation in children with asthma: a randomized, placebo-controlled trial in northern Islamic Republic of Iran. East Mediterr Health J 2014;20:391-96. 